\title{
EFFECTS OF RECONSTITUTION OF HIGH TANNIN SORGHUM GRAIN ON SMALL INTESTINE MORPHOMETRY OF JAPANESE QUAILS
}

\author{
Emami Fayyaz, Maheri-Sis Naser* \\ Department of Animal Sciences, Shabestar Branch, Islamic Azad University, Shabestar, Iran
}

\begin{abstract}
This study was performed to evaluate the effects of substituting corn grain by reconstituted or unreconstituted sorghum grain on small intestine morphometry in Japanese quails. Seven hundred day-old unsexed quail chicks were fed basal diet and raised in cage system for 20 day. At day 21, 300 male quail chicks with same weight, selected and reared till 42 days of age. Selected birds were divided into 5 treatments (4 replicates contain 15 birds per pen). Experimental treatments were: (A) diet contains corn grain and without sorghum (control) (B) replacing 50\% reconstituted sorghum (C) replacing 50\% unreconstituted sorghum (D) replacing 100\% reconstituted sorghum and (E) replacing 100\% un-reconstituted sorghum grain in place of corn grain, respectively. According to the results, replacing 100\% reconstituted in place of corn grain significantly increased average villi length in $10 \%$ and $70 \%$ sections of small intestine length in day $42(\mathrm{P}<0.05)$. Furthermore, a significant increase was observed on average depth of liberkuhn crypts after replacing $100 \%$ reconstituted in place of corn grain $10 \%$ and $70 \%$ section of small intestine length in Japanese quail $(\mathrm{P}<0.05)$. Moreover, a significant decrease was observed on average villus length and depth of liberkuhn crypts in 10\% section of small intestine length in birds fed $100 \%$ unreconstituted compared to control group $(\mathrm{P}<0.05)$. In conclusion, replacing reconstituted sorghum had better effects than un-reconstituted sorghum on average villi length and average depth of liberkuhn crypts of Japanese quail.
\end{abstract}

Keywords: reconstitution, sorghum, villi length, liberkuhn crypts, Japanese quails

\section{INTRODUCTION}

Poultry meat industry is greatly dependent on supply of energy sources from grains that are known to vary widely in nutritive value. Sources are varies in the physical and chemical characteristics e.g. variety, seasonal effects and growth sites, crop treatment and grain fumigants, and post-harvest storage conditions and period of storage as used in poultry diets [1]. Feed is the principal single cost factor in production of chicken meat. Variation in the available energy and protein content of grains can be attributed to a wide range of anti-nutritive factors such as non-starch polysaccharides (NSP), Tannins, inhibitors, alkaloids, phytohaemagglutinins, saponins, and lathyrogens. The relative importance of such factors will also differ according to the type of grain in question [2].

*Correspondence to: Maheri-Sis Naser, Department of Animal Sciences, Shabestar Branch, Islamic Azad University, Shabestar,Iran,nama1349@gmail.com
Sorghum is fairly cheaper and easy to cultivate than maize. According to Subramanian and Metta [3], sorghum grain is as ideal as maize for poultry. Likewise, Augusto et al., [4] reported that, sorghum can replace in term of maize in poultry diets provided xanthophylls are added for skin and egg yolk pigmentation. Also comparing sorghum with maize was showed that sorghum had better results than maize grain in turkey [5].

Sorghum is sole among cereals in that produce large amounts of tannins [6]. Tannins are plant secondary metabolites that are characteristically rich in phenolic hydroxyl groups. Both major structural classes of tannins are widely distributed in plants: hydrolyzable tannins (HT) and condensed tannins (CT). Tannins exhibit a wide variety of biological effects thought to be caused by their capacity to bind and coagulate proteinaceous tissue (astringency) [7]. Mature grain of sorghum (Sorghum bicolor L.) may 
FAYYAZ E., et al.

contain $2 \%$ or more CT, while immature grain of high-tannin sorghums shows even higher levels of tannin in chemical assays. Hydrolyzable tannins have not been reported from sorghum. Under ideal conditions, sorghum tannin is capable to bind and precipitate proteins 12 times more than its own weight. Because sorghum grain contains $10 \%$ protein, the grain of hightannin cultivars contains more than enough tannin to bind all the seed protein, thus profoundly affecting the properties of the protein [7].

Utilization of energy by the chicken will be influenced by requirements for growth and maintenance of the Gastrointestinal tract (GIT) [1], intestinal epithelium surface and villus height $[8,9]$. The relative opportunities for contact between ingested food, digestive enzymes, bile salts and the time available for contact between digested particles and absorptive surfaces are likely to influence by tannins in chicken. Tannins may also bind endogenous enzymes in the GIT and inhibit their activity [7]. Growth performance and nutrient absorption are influenced by rate of passage of digesta in chickens [10, 11] and rats [12]. Moreover, Welsch et al., [13] demonstrated that dietary phenolic compounds and tannic acid in particular, inhibited glucose uptake via $\mathrm{Na}^{+}$ dependent transport systems in small intestinal brush border membrane vesicles in rats. Furthermore, the presence of anti-nutritional factors such as tannins may also lead to decrease digestibility [14]. There is evidence that tannins have a detrimental effect on the GIT digestibility of protein and amino acids $[15,16]$. Therefore it seems that, lowering tannin content of high tannin sorghum grain leading to improvement of GIT performance. Between different chemical and physical treatment methods, reconstitution is an efficient and simple process for lowering tannin content in feeds in sorghum grain. In this method, dry matter content of grains decreased to $70-75 \%$ by water adding and then stored in anaerobic conditions for three weeks [17].

Based on previous studies on effects tannin containing foodstuff on gastrointestinal physiology in poultry our hypothesis on this article was to effects of replacing corn grain by reconstituted (RS) or un-reconstituted (URS) sorghum grain on average villi height and depth of liberkuhn crypts in various sections of small intestine length in Japanese quails.

\section{MATERIALS AND METHODS Birds and diets}

Seven hundred day-old mixed sex quail chicks (Coturnix coturnix japonica) were fed same diets and reared in cage system for first 20 day after hatch. At $21^{\text {th }}$ days of age, quails were sexed based on their breast feather color and 300 male chicks with same weight raised for 21 day experimental period (days 21-42). Experimental birds were divided into 5 treatment groups (4 replicates contain 15 birds per each pen). Treatment groups were received experimental diets: (A) diet contains corn grain and without sorghum grain (B) replacing 50\% RS sorghum grain (C) replacing 50\% URS sorghum (D) replacing $100 \%$ RS sorghum grain and (E) replacing $100 \%$ URS sorghum in place of corn grain, respectively. Isoenergetic and isonitrogenous diets were formulated according to nutritional suggestions of NRC [18]. Chemical composition of reconstituted (RS) and unreconstituted (URS) sorghum grain as well as experimental diets, already published by our research team in detail [17]. The arrangement of diets for experimental treatments is shown in Table 1.

Table 1. Arrangement of diets offered to different treatments of Japanese quails at experimental period $(21-42 d)$

\begin{tabular}{lccccc}
\hline Treatments & $\mathrm{A}$ & $\mathrm{B}$ & $\mathrm{C}$ & $\mathrm{D}$ & $\mathrm{E}$ \\
\hline $\begin{array}{l}\text { Main } \\
\text { Ingredients }\end{array}$ & $\begin{array}{c}0 \% \\
\text { sorghum } \\
\text { (Control) }\end{array}$ & $\begin{array}{c}50 \% \\
\text { sorghum } \\
\text { (RS) }\end{array}$ & $\begin{array}{c}50 \% \text { sorghum } \\
\text { (URS) }\end{array}$ & $\begin{array}{c}100 \% \\
\text { sorghum } \\
\text { (RS) }\end{array}$ & $\begin{array}{c}100 \% \\
\text { sorghum } \\
\text { (URS) }\end{array}$ \\
\hline $\begin{array}{l}\text { Corn grain } \\
(\%)\end{array}$ & 50 & 25 & 25 & 0 & 0 \\
$\begin{array}{l}\text { Sorghum grain } \\
(\%)\end{array}$ & 0 & 25 & 25 & 50 & 50 \\
\hline
\end{tabular}

Control: no corn grain replaced by sorghum grain; RS: reconstituted sorghum; URS: un-reconstituted sorghum 
FAYYAZ E., et al.

\section{Preparation Sorghum grain}

Sorghum grains were purchased from farms of the Miyaneh region, East Azerbaijan, Iran. Half of grains reconstituted by adding water to whole grain to raise the moisture level to $30 \%$ (DM $70 \%$ ), followed by anaerobic storage in sealed plastic buckets for 21 days at room temperature, and then the grains were sun-dried, until the dry matter content reached about $90 \%$. After sun drying, grains ground for using in diet of Japanese quails [20].

\section{Intestinal morphology}

At the end of the experiment (42 days of age), about six hours before to start of the killing, animals were deprived from food. Two birds from each group with body weight near to the medium body weight for that group selected and slaughtered. Animals necropsied, and the entire gastrointestinal tract was quickly removed for further studies. Various sections of small intestine $(10,50$ and $70 \%$ of small intestine length) sampled [20], rinsed with phosphate to measure villi length and depth of liberkuhn crypts. Each sample was divided into 2 parts. One part for measuring villus dimensions and second one for determining depth of liberkuhn crypts. Each sample was prepared for microscopically study after staining with Periodic Acid Schiff Solution (PAS), separating muscular layer and preparing lamella. In each sample, villi height was measured from the top to the bottom of villus. Mean villi heights and depth of liberkuhn crypts from 2 birds (40 villi from different sections in each sample per bird) were attributed as a mean villi height in each group using the second sample per birds using an image Analyzer (Nikon Cosmozone 1S; Nikon Co., Tokyo, Japan) in the physiology laboratory of Islamic Azad University, Shabestar Branch, Iran.

\section{Statistical analysis}

Data were analyzed by one-way analysis of variance (ANOVA) in a completely randomized design and treatment means were tested for statistical significance by Tukey's Range Test using SAS statistical software [21].

\section{RESULTS AND DISCUSSION}

Effects of replacing corn grain by reconstituted or un-reconstituted sorghum grain on average villi height and depth of liberkuhn crypts in various sections of small intestine length in Japanese quails in day 42 are presented in Tables 2 and 3. According to the data there was a significant increase in average villi length in
$10 \%$ section of small intestine length after replacing $100 \% \mathrm{RS}$ in place of corn grain in Japanese quails $(\mathrm{P}<0.05)$. Furthermore, similar results was observed after replacing $100 \%$ RS in place of corn grain on average depth of liberkuhn crypts (10\% section of small intestine length) in day $42 \quad(\mathrm{P}<0.05)$. Moreover, a significant decrease was observed on average villus length and depth of liberkuhn crypts in $10 \%$ section of small intestine length in birds fed $100 \%$ URS compared to control group $(\mathrm{P}<0.05)$. Previously, Uni et al., [22] studied changes in the structure and function of the duodenum, jejunum and ileum in broilers from hatch to 14 days of age. They noted that development of the small intestine was rapid from day 2 after hatch but that the rates of development differed between the segments of the small intestine. Villus volume in the duodenum reached a plateau after 7 days but continued to increase in the jejunum and ileum. Indices of tissue activity, ribosomal capacity, and cell size decreased with age but at differing rates in these intestinal sections. Because lack of any published data on the field of current study, we could not compare our results with. In case of comparing villi height and depth of liberkuhn crypts in various sections of small intestine length in Japanese quails, data obtained in current study were in line with those reported by Zahedi et al [23].

As shown in table 3, replacing of any portion of sorghum (B-E treatments) significantly decreased on average villus length and depth of liberkuhn crypts in various sections of small intestine length (50\%) compared to control group fed corn grain in Japanese quails in day 42 $(\mathrm{P}<0.05)$. Tannins have been proposed to interfere with intestinal protective mucus glycoproteins, thus increasing the excretion of endogenous nitrogen from mucus. It has also been shown that dietary tannins were able to bind intestinal brush border proteins as well as luminal digestive enzymes such as trypsin and $\alpha$ amylase [24]. These processes have been demonstrated in monogastric animals (rats, pigs and especially chickens with significant damage to the intestinal mucosa and poor absorption of amino acids, especially with chickens [25]. Moreover, histological changes including atrophy and shortening of villi with distortion of their architecture were observed in the ileal mucosa of chicks and to a lesser extent in rats when fed diets containing a freeze-dried tannin extract $(1.6 \%)$ from faba beans (Vicia faba L.) [26]. In this study, replacing of URS showed 
FAYYAZ E., et al.

negative effects on average villus length and depth of liberkuhn crypts in various sections of small intestine (10, 50 and 70\%) compared to RS sorghum. It seems, the reverse effects were related to tannin content of untreated sorghum. Perhaps further researches need to investigate direct effects of tannin on intestinal morphology in Japanese quail. Based on our previous researches there was no significant difference after feeding reconstituted sorghum on carcass yield and carcass components as well as edible internal organs of Japanese quails. Moreover, replacing $50 \%$ or $100 \%$ sorghum grain in place of corn grain has not adverse effect on carcass characteristics in Japanese quails [27]. However, using $100 \%$ sorghum grain in place of corn grain led to decrease growth performance of Japanese quails [17].

Table 2. Effects of replacing corn grain by reconstituted or un-reconstituted sorghum grain on average villi height $(\mu \mathrm{m})$ and depth of liberkuhn crypts $(\mu \mathrm{m})$ in various sections of small intestine in Japanese quails at day 42

\begin{tabular}{|c|c|c|c|c|c|c|}
\hline \multirow{2}{*}{$\begin{array}{c}\text { Of intestine } \\
\text { length }\end{array}$} & \multicolumn{2}{|c|}{$\begin{array}{c}10 \% \\
\text { (Duodenum) }\end{array}$} & \multicolumn{2}{|c|}{$\begin{array}{c}50 \% \\
\text { (Jejunum) }\end{array}$} & \multicolumn{2}{|c|}{$\begin{array}{l}70 \% \\
\text { (Ileum) }\end{array}$} \\
\hline & $\begin{array}{l}\text { Villi } \\
\text { height }\end{array}$ & $\begin{array}{l}\text { Depth of } \\
\text { liberkuhn } \\
\text { crypts }\end{array}$ & Villi height & $\begin{array}{l}\text { Depth of } \\
\text { liberkuhn } \\
\text { crypts }\end{array}$ & Villi height & $\begin{array}{l}\text { Depth of } \\
\text { liberkuhn } \\
\text { crypts }\end{array}$ \\
\hline (A) control & $284.93^{b}$ & $65.68^{b}$ & $221.28^{\mathrm{a}}$ & $58.26^{\mathrm{a}}$ & $120.01^{c}$ & $53.71^{\mathrm{a}}$ \\
\hline (B) $50 \% \mathrm{RS}$ & $258.82^{c}$ & $61.33^{b c}$ & $147 / 06^{\mathrm{c}}$ & $37.80^{\mathrm{c}}$ & $126.00^{\mathrm{c}}$ & $32.66^{\mathrm{c}}$ \\
\hline (C) $50 \%$ URS & $216.00^{\mathrm{d}}$ & $57.04^{b c}$ & $162.15^{b c}$ & $52.27^{\mathrm{ab}}$ & $160.28^{b}$ & $42.65^{b}$ \\
\hline (D) $100 \% \mathrm{RS}$ & $354.42^{\mathrm{a}}$ & $92.40^{\mathrm{a}}$ & $171.75^{b}$ & $50.94^{\mathrm{ab}}$ & $212.57^{\mathrm{a}}$ & $44.17^{b}$ \\
\hline (E) $100 \%$ & $262.67^{b c}$ & $53.44^{\mathrm{c}}$ & $171.32^{b}$ & $46.10^{\mathrm{b}}$ & $152.37^{b}$ & $42.50^{b}$ \\
\hline URS & & & & & & \\
\hline P value & 0.0001 & 0.0001 & 0.0001 & 0.0001 & 0.0001 & 0.0001 \\
\hline SEM & 6.14 & 2.39 & 4.28 & $1 . .82$ & 4.32 & 1.99 \\
\hline
\end{tabular}

Control: no corn grain replaced by sorghum grain; RS: reconstituted sorghum; URS: un-reconstituted sorghum. SEM: standard error of mean. There are significant differences between groups with different codes in a column (superscript letters a, b, c and d; $\mathrm{p}$ < 0.05).

Table 3. Effects of replacing corn grain by reconstituted or un-reconstituted sorghum grain on average villi height and depth of liberkuhn crypts in various sections of small intestine in Japanese quails at day 42 [presented as relative values (\%) compared to the data for the control group]

\begin{tabular}{|c|c|c|c|c|c|c|}
\hline \multirow{2}{*}{$\begin{array}{c}\text { Of intestine } \\
\text { length }\end{array}$} & \multicolumn{2}{|c|}{$\begin{array}{c}10 \% \\
\text { (Duodenum) }\end{array}$} & \multicolumn{2}{|c|}{$\begin{array}{c}50 \% \\
\text { (Jejunum) }\end{array}$} & \multicolumn{2}{|c|}{$\begin{array}{l}70 \% \\
\text { (Ileum) }\end{array}$} \\
\hline & $\begin{array}{c}\text { Villi } \\
\text { height }\end{array}$ & $\begin{array}{l}\text { Depth of } \\
\text { liberkuhn } \\
\text { crypts }\end{array}$ & Villi height & $\begin{array}{l}\text { Depth of } \\
\text { liberkuhn } \\
\text { crypts }\end{array}$ & Villi height & $\begin{array}{l}\text { Depth of } \\
\text { liberkuhn } \\
\text { crypts }\end{array}$ \\
\hline (A) control & $100^{b}$ & $100^{b}$ & $100^{\mathrm{a}}$ & $100^{\mathrm{a}}$ & $100^{\mathrm{c}}$ & $100^{\mathrm{a}}$ \\
\hline (B) $50 \% \mathrm{RS}$ & $90.83^{\mathrm{c}}$ & $93.38^{\mathrm{bc}}$ & $66.46^{\mathrm{c}}$ & $64.87^{\mathrm{c}}$ & $104.97^{\mathrm{c}}$ & $60.81^{\mathrm{c}}$ \\
\hline (C) $50 \%$ URS & $75.81^{\mathrm{d}}$ & $86.84^{\mathrm{bc}}$ & $73.28^{\mathrm{bc}}$ & $89.72^{\mathrm{ab}}$ & $133.55^{\mathrm{b}}$ & $79.41^{b}$ \\
\hline (D) $100 \% \mathrm{RS}$ & $124.38^{\mathrm{a}}$ & $140.68^{a}$ & $77.62^{\mathrm{b}}$ & $87.44^{\mathrm{ab}}$ & $126.96^{b}$ & $82.25^{\mathrm{b}}$ \\
\hline (E) $100 \%$ & $92.15^{\mathrm{bc}}$ & $81.35^{\mathrm{c}}$ & $77.43^{\mathrm{b}}$ & $79.13^{\mathrm{b}}$ & $177.12^{\mathrm{a}}$ & $79.13^{\mathrm{b}}$ \\
\hline URS & & & & & & \\
\hline$P$ value & 0.0001 & 0.0001 & 0.0001 & 0.0001 & 0.0001 & 0.0001 \\
\hline SEM & 2.16 & 3.40 & 1.94 & 3.12 & 3.60 & 3.72 \\
\hline
\end{tabular}

Control: no corn grain replaced by sorghum grain; RS: reconstituted sorghum; URS: un-reconstituted sorghum. SEM: standard error of mean. There are significant differences between groups with different codes in a column (superscript letters a, b, c and d; $\mathrm{p}<0.05$ ).

In this study, replacing $100 \%$ URS instead of corn grain significantly improved average villi length in $70 \%$ of small intestine length in experimental birds after 42 days $(\mathrm{P}<0.05)$. In addition, average depth of liberkuhn crypts significantly diminished after replacing of $50 \%$ RS, $50 \%$ URS, $100 \%$ RS and $100 \%$ RS in place of corn grain $(\mathrm{P}<0.05)$. High levels of CTs are 
FAYYAZ E., et al.

detrimental to livestock production. However, mixed grazing/ browsing has the potential to reduce total CT intake yet still retain the benefits of tannins on protein flow to the small intestine [28]. In previous reports, there were no reverse effects on small intestine morphometry using diets containing high or low tannin levels. Also, a slight lessening was observed on depth of liberkuhn crypts in broilers [29]. There was a general trend for villus height to decrease numerically from the proximal to the distal section of the small intestine. A similar tendency for villous height and crypt depth to decrease distally along the small intestine was observed in pigs by Van Leeuwen et al., [30]. It seems, tannin impress its final effects on tissue activity, ribosomal capacity or on cell size in small intestine. Condensed tannins are clearly a "double edged sword" for feeding value. They are not digested and the carbon skeleton is not absorbed so high concentrations of CT reduce the DM potentially available for digestion. Understanding their effects on digestive physiology is complex [25]. The impact of reduced cell turnover on nutrient digestibility in the small intestine of quail remains unknown and requires further investigation. These results indicate that presumably these effects occur because of tannin content in sorghum grain replaced in term of corn in quails fed. It seems that, further researches needs to elucidate the direct effects of sorghum on villi height and depth of liberkuhn crypts in quail.

\section{CONCLUSION}

As a conclusion, beseems reconstitution of the high tannin sorghum grain can be results in improving height of villus and depth of liberkuhn crypts in various sections of small intestine length in particular in case of high substation rate of sorghum $(100 \%)$ in place of maize grain in Japanese quail diet. However, further investigations requires for further knowledge on precise effects of sorghum tannins on morphology of small intestine of different species of poultry.

\section{ACKNOWLEDGMENTS}

This article is a part of M.Sc. thesis in animal science, Islamic Azad University, Shabestar Branch (thesis supervisor: Dr. Naser MaheriSis). We would like to acknowledge Dr Jamshid Ghiasi, Dr Behrad Eshratkhah and Mr. Shahin Hassanpour as well as Dr. Abolfazl Gorbani and
Dr. Tohid Vahdatpour for their critical and valuable assistance.

\section{REFERENCES}

1. Choct M., Soluble non-starch polysaccharides affect net utilisation of energy by chickens. Rec. Adv. Anim. Nutr. Aust., 12, 31-35, 1990.

2. Hughes R.J., Choct M., Chemical and physical characteristics of grains that are related to variability in energy and amino acid availability in poultry. Aust. J. Agric. Res., 50, 689-701, 1999.

3. Subramanian V., Metta V.C., Sorghum grain for poultry feed. In: Technical and Institution Options for Sorghum Grain Mold Management. Proc. International Consultation. Chandrasher A, Bandyopadhayi R and Hall AJ (eds.). International Crop Research for the SemiArid Tropics (ICRISAT). Patacheru 502 504, Andhra Pradesh, India, pp: 242 -247, 2000.

4. Augusto A.M., Cauca G., Pino J.A., Poultry nutrition in Latin America with special reference to scientific poultry rearing. In: Animal Production in the Tropics. JK Loosli, VA Oyenuga and GM Babatunde (eds.). Heineman Education Books Nigeria Plc, Ibadan, p. 219, 1974.

5. Pro M.A., Cuca M., La Utilization del Trigo Como Fuente de Energia en la Alimentacion de Pavos en Iniciacion. Tech Pec. en Mex., 11, $44-45,1968$.

6. Cheeke P.R., Natural Toxicants in Feeds, Forages and Poisonous Plants. 2nd Ed. Interstate Publishers, Illinois, 1998.

7. Hassanpour S., Sadaghian M., Maheri Sis N., Eshratkhah B. and Chaichi Semsari M., Effect of condensed tannin on controlling faecal protein excretion in nematodeinfected sheep: in vivo study. J. Am. Sci., 7, 896-900, 2011.

8. Jin S., Corless A., Sell J.L., Jin S.H., Digestive system development in post-hatch poultry. World Poultry Sci. J., 54, 335-345, 1998.

9. Iji P.A., The impact of cereal non-starch polysaccharides on intestinal development and function in broiler chickens. World Poultry Sci. J., 55, 375-3871, 999.

10. van der Klis, J.D., van Voorst A., The effect of carboxy methyl cellulose (a soluble polysaccharide) on the rate of marker 
FAYYAZ E., et al.

excretion from the gastrointestinal tract of broilers. Poultry Sci., 72, 503-512, 1993.

11. Uni Z., Noy Y., Sklan D., Post hatch changes in morphology and function of the small intestines in heavy- and light-strain chicks. Poultry Sci., 74, 1622-1629, 1995.

12. Gohl B., Gohl I., The effect of viscous substances on the transit time of barley digesta in rats. J. Sci. Food Agric., 28, 911915, 1977.

13. Welsch C.A., Lachance P.A., Wasserman B.P., Effects of native and oxidized phenolic compounds on sucrase activity in rat brush border membrane vesicles. $J$. Nutr., 119, 1737- 1740, 1989.

14. Kondos A.C., Foale M.A., Comparison of the nutritional value of low and medium tannin sorghum grains for pigs. Anim. Feed Sci. Technol., 8, 85-90, 1983.

15. Cousins B.W., Tanksley T.D., Knabe D.A., Zebrowska T., Nutrient digestibility and performance of pigs fed sorghums varying in tannin concentration. J. Anim. Sci., 53, 1524-1537, 1981.

16. Brand T.S., Badenhorst H.A., Siebrits F.K., The use of pigs both intact and with ileorectal anastomosis to estimate the apparent and true digestibility of amino acids in untreated, heat-treated and thermalammoniated high-tannin grain sorghum. $S$. Afr. J. Anim. Sci., 20, 223-228, 1990.

17. Emami F., Maheri-Sis N., Ghorbani A., Vahdatpour T., Effects of feeding untreated or reconstituted sorghum grain (Sorghum bicolor L.) on growth performance of Japanese quails (Coturnix coturnix japonica). Int. J. Biosci., 2, 31-37, 2012.

18. NRC., Nutrient Requirements of Poultry. Washington, D.C., National Academy Press, 9 revised edition, 155p, 1994.

19. AOAC., Official Methods of Analysis.15th (ed.) Assoc. Offic. Anal. Chem., Arlington, VA, 1990.

20. Kumar V., Elangovan A.V.A., Mandal B., Tyagi P.K., Bhanja S.K., Dash B.B., Effects of feeding raw or reconstituted high tannin red sorghum on nutrient utilisation and certain welfare parameters of broiler chickens. Br. Poultry. Sci., 48, 198-204, 2010.

21. SAS Inc. SAS OnlineDoc ${ }^{\circledR}$ 9.1.3. Cary, NC, USA, 2007.
22. Maunder B., Sorghum - The global grain of the future. Retrieved November 30, 2004 from http://www.sorghumgrowers.com/maunder. htm. 2002.

23. Uni Z., Ganot S., Sklan D., Posthatch development of mucosal function in the broiler small intestine. Poultry Sci., 77, 75821, 1998.

24. Zahedi M., Ghiasi Ghalehkandi J., Ebrahimnezhad Y., Effects of different levels of copper sulfate on small intestinal physiology in Japanese quail (Coturnix coturnix japonica), Int. J. Biosci., 3, 252257, 2013.

25. Al-Mamary M., Al-Habori M., Al-Aghbari A., Al-Obeidi A., In vivo effects of dietary sorghum tannins on rabbit digestive enzymes and mineral absorption. Nutr. Res. 21, 1393-1401, 2001.

26. Waghorn G., Beneficial and detrimental effects of dietary condensed tannins for sustainable sheep and goat productionProgress and challenges. Anim. Feed Sci. Technol., 147,116-139, 2008.

27. Ortiz L.T., Alzueta C., Trevino J., Castano M., Effects of faba bean tannins on the growth, and histological structure of the intestinal tract, and liver of chicks and rats. Br. Poultry Sci., 35, 743-54, 1994.

28. Waghorn G.C., Shelton I.D., Effect of condensed tannins in Lotus pedunculatus on the nutritive value of ryegrass (Lolium perenne) fed to sheep. J. Agric. Sci., 125, 291-297, 1995.

29. Emami F., Maheri-Sis N., Ghorbani A., Vahdatpour T., Effects of replacing corn grain by reconstituted or un-reconstituted sorghum grain on carcass characteristics of Japanese quails (Coturnix coturnix japonica). Int. J. Biosci., 2, 90-96, 2012.

30. Sell D.R., Reed W.M., Chrisman C.L., Rogler J.C., Mucin excretion and morphology of the intestinal tract as influenced by sorghum tannins. Nutr. Rep. Int., 31, 1369-1374, 1985.

31. Van Leeuwen P., Jansman A.J.M., Wiebenga J., Koninkx J.F.J.G., Mouwen J.M.V.M., Dietary effects of fababean (Vicia faba L.) tannins on themorphology and function of the small-intestinal mucosa of weaned pigs. Br. J. Nutrition, 73, 31-39, 1995. 